\title{
Studies Toward the Total Synthesis of Seselidiol
}

\author{
Marcelo F. R. Silva ${ }^{1 \star}$, Dayvson J. Palmeira, ${ }^{2}$ Leandro H. Andrade, ${ }^{2}$ and \\ Paulo H. Menezes ${ }^{1}$ \\ ${ }^{1}$ Departamento de Química Fundamental, CCEN, UFPE, 50670-901, Recife-PE, Brasil \\ ${ }^{2}$ Instituto de Química, USP, Av. Prof. Lineu Prestes, 748, Butantã, São Paulo-SP, Brasil \\ *marcelo.frsilva@ufpe.br
}

Keywords: seselidiol, vinyl tellurides, antitumoral

\section{INTRODUCTION}

$( \pm)$-Seselidiol (Figure 1) a natural product isolated in $0.0085 \%$ yield from the roots of Seseli mairei Wolff (Umbelliferae) and used as herbal remedies for human inflammation, swelling, rheumatism, pain, and common cold in folk medicine.

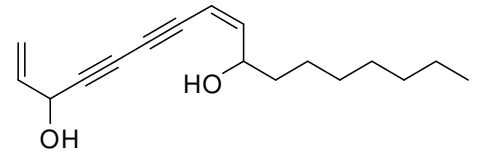

Figure 1: Seselidiol (1)

It also showed significant cytotoxicity in $\mathrm{KB}, \mathrm{P}-388$, and $\mathrm{L}-1210$ tumor cells $\left(\mathrm{ED}_{50}<20 \mu \mathrm{g} / \mathrm{mL}\right) .{ }^{1}$ The absolute stereochemistry of the stereogenic centers in Seselidiol is not known. Although its biological activity is known for over twenty years, due to date no total synthesis of the natural product has been attempted. These facts motivated us to propose a synthetic strategy for preparation.

\section{RESULTS AND DISCUSSION}

In our disconnection approach, $\mathbf{1}$ was divided into two main intermediates, A and B (Figure 2).

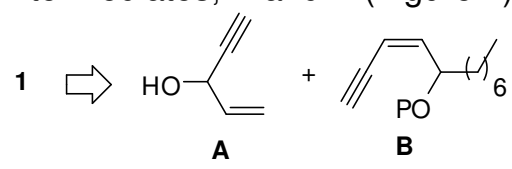

Figure 2. Retrossynthetic for Seselidiol

The fragment $\mathbf{A}$ was synthesized from the appropriate lithium acetylide with acrolein (figure 3).

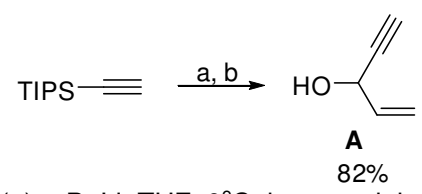

Scheme 1: (a) $n$-BuLi, THF, $0^{\circ} \mathrm{C}$ then acroleine; (b) $\mathrm{K}_{2} \mathrm{CO}_{3}$, $\mathrm{MeOH}, 25^{\circ} \mathrm{C}, 3 \mathrm{~h}$

The synthesis of fragment B started from 1-octanal. Addition of ethynylmagnesium bromide at room temperature gave alcohol $\mathbf{2}$ which was converted into its TIPS derivative $\mathbf{3}$ and submitted to the hydrotelluration reaction to give the corresponding $Z$-vinyl telluride 4 as a single isomer determined by ${ }^{1} \mathrm{H}$, and confirmed by ${ }^{125} \mathrm{Te}$ NMR. ${ }^{2}$ Further coupling reaction $^{3}$ with TMS-acetylene gave Fragment $\mathrm{B}$ (Scheme 2).



only isomer

Scheme 2: (a) ethynylmagnesium bromide, THF, $25^{\circ} \mathrm{C}, 12 \mathrm{~h}$ (50\%); (b) TIPSCl, imidazole, DMF, $25^{\circ} \mathrm{C}, 12 \mathrm{~h}$ (85\%); (c) BuTeTeBu, $\mathrm{NaBH}_{4}, \mathrm{EtOH}$, reflux, 5h (90\%); (d) TMS-acetylene, $\mathrm{PdCl}_{2}, \mathrm{Cul}, \mathrm{Et}_{3} \mathrm{~N}, \mathrm{MeOH}, 3 \mathrm{~h}, 25^{\circ} \mathrm{C}(75 \%)$.

It is noteworthy that when the hydrotelluration reaction was performed using 2 as the alkyne source, a mixture of 78:22 of the two regioisomers was observed.

The enzymatic resolution of the fragments $\mathbf{A}$ and $\mathbf{B}$ as well as the coupling reaction between them are in progress in our laboratories.

\section{CONCLUSION}

In summary, two advanced intermediates in the synthesis of Seselidiol were achieved. The synthesis features the use of a vinyl-telluride for the preparation of the $Z$ double bond present in the natural product. Further progress toward the asymmetric synthesis of Seselidiol will be reported in the due course.

\section{ACKNOWLEDGEMENTS}

The authors gratefully acknowledge CNPq, CAPES, FACEPE and INCT-INAMI for the financial support.

\section{REFERENCES}

${ }^{1}$ Hu, C.-Q.; Chang, J.-J.; Lee, K.-H. J. Nat. Prod. 1990, 53, 932.

${ }^{2}$ Oliveira, J. M. ; Palmeira, D. J. ; Comasseto, J. V. ; Menezes. P. H. J. Braz. Chem. Soc. 2010, 21, 362-366

Zeni, G., Comasseto, J. V. Tetrahedron Lett. 1999, 40, 4619. 